\title{
"Melyik volt a legjobb harckocsi?" gyakran feltett kérdés, hibás válaszokkal
}

A z interneten könnyen rátalálunk a „Top 10”, „Top 5” legjobb mai harckocsikat bemutató látványos filmekre. Ezek igazán élvezetesek, de alig közepes az információ-tartalmuk. Sok vita nincs is körülöttük. Annál inkább a 2. világháború ismert híres harckocsijairól, páncélosairól. Nem véletlenül, hiszen ezekről könyvek tucatjai, nagyszerű művészi filmek, ismertetők sora, vitafórumok indulatos hozzászólásai tudósítanak. Itt valóban arról van szó, melyik volt a jobb, a tűzerősebb, a gyorsabb, melyik pusztított el többet az ellenség soraiból. A vita, amely igen gyakran a nehéz harckocsik összevetése kapcsán bontakozik ki, érdekfeszítő, sőt többnyire indulatos is. De hogyan várható meggyőző és jó válasz, ha a megközelítések egysíkúak, a hibás érvelések generációkon át egymásra támaszkodnak, és az egykori propaganda hatása még ma is gátolja a sokoldalúan megalapozott, tudományos elemzést és értékelést?

Lehetne másképpen is?

Állítom, hogy igen, és ennek alátámasztására mutatok be - mozaikszerűen - néhány tudományos igényű módszert, új műszaki és hadtudományi megközelítési lehetőséget.

Miért a nehéz harckocsi?

A harckocsik fejlődése a második világháborúban igazán nagy ívű volt. A nehéz harckocsik ezen belül különös helyet

1. ábra. Német Panther harckocsi egy haditechnikai parkban

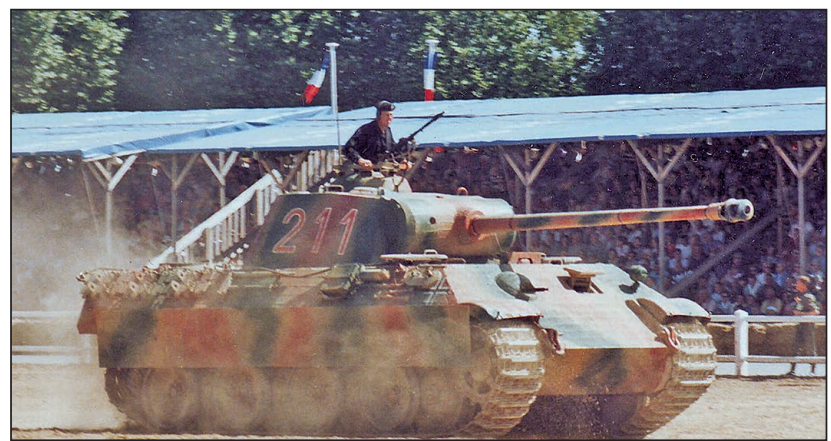

ÖSSZEFOGLALÁS: A második világháború első, második és harmadik legjobb harckocsijának rangsorolása a katonai szakirodalmat keleten és nyugaton egyaránt foglalkoztatta, és foglalkoztatja még ma is. A tanulmány a katonaimüszaki tudományterület legkorszerübb elemzési módszereit, egyebek mellett a Kesselring-módszert, a konstrukciós megoldások generációs táblázatát, illetve a hadászati kultúrák által támasztott alkalmazói igény szerinti elemzés módszerét egyaránt alkalmazva törekszik annak a kérdésnek a megválaszolására, hogy melyik volt a második világháború legjobb nehéz harckocsija.

KULCSSZAVAK: II. világháború, nehéz harckocsi, Tiger, Panther, Königstiger, KV-1, ISz-2, ISz-3, Tas, Churchill, M-26

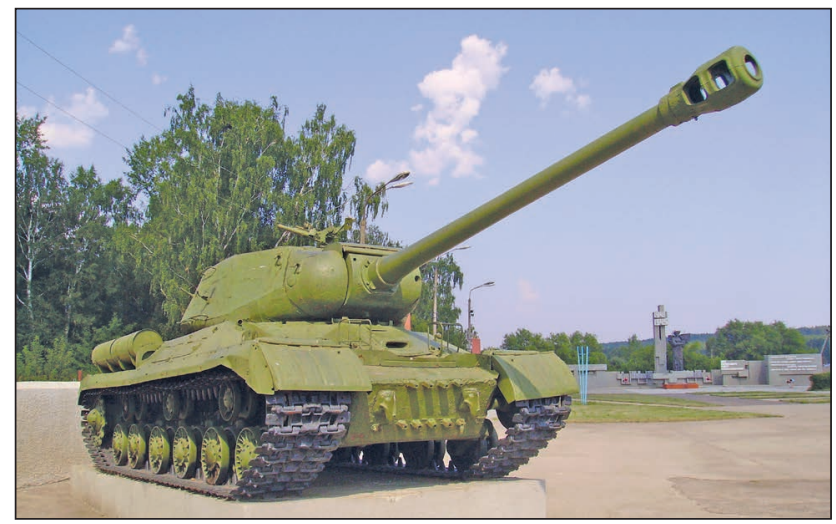

2. ábra. Szovjet ISz-2-es harckocsi

foglaltak el, hiszen a háború vége felé ebben a kategóriában alakult ki a legnagyobb verseny. A müszaki problémák és a legnehezebben megoldható harci (alkalmazói) feladatok is itt sokasodtak. Nem véletlen tehát, hogy az érdeklödés igen nagy ezek iránt az „óriások” iránt. A háborús megmérettetéseik óta eltelt jelentős időszak lehetségessé és szükségessé is teszi, hogy megítélésük kellően megalapozott és megfontoltan sokoldalú legyen.

Milyen „lépéseket” célszerű megtennünk ahhoz, hogy kellő körültekintéssel tehessünk megállapításokat az alkalmassági sorrend (értéksorrend) felállítására?

A válasz természetesen több szempontú vizsgálatot igényel, amelynek fontos lépései lehetnek:

- a szakirodalom alapján kialakult általános vélemény megismerése;

- a legfontosabb harcászati műszaki jellemzők (tűzerő, védettség, mozgékonyság) értékeinek összegyűjtése és összevetése

- a konstrukciós fejlettség, korszerűség vizsgálata;

- az értékelt harckocsi típusok és a nemzeti haderők által képviselt hadászati kultúrák összhangjának vizsgálata és minősítése.

ABSTRACT: Which one was the first, second and third best tank of the World War II? Both Eastern and Western military literature were and are even today being concerned about this ranking. Applying equally the state of the art anaIytical methods of the military technological scientific field, inter alia the Kesselring method, the generation table of design solutions or analysis according to the user's demand made by the operations cultures, this study tries to answer the question above.

KEY WORDS: World War II, heavy tank, Tiger, Panther, Königstiger, KV-1, ISz-2, ISz-3, Tas, Churchill, M-26

\footnotetext{
Prof. Dr. Turcsányi Károly nyá. mk. ezredes, Professor Emeritus, Nemzeti Közszolgálati Egyetem (National University of Public Service) Hadtudományi Kar, ORCID: 0000-0002-0161-6718
} 


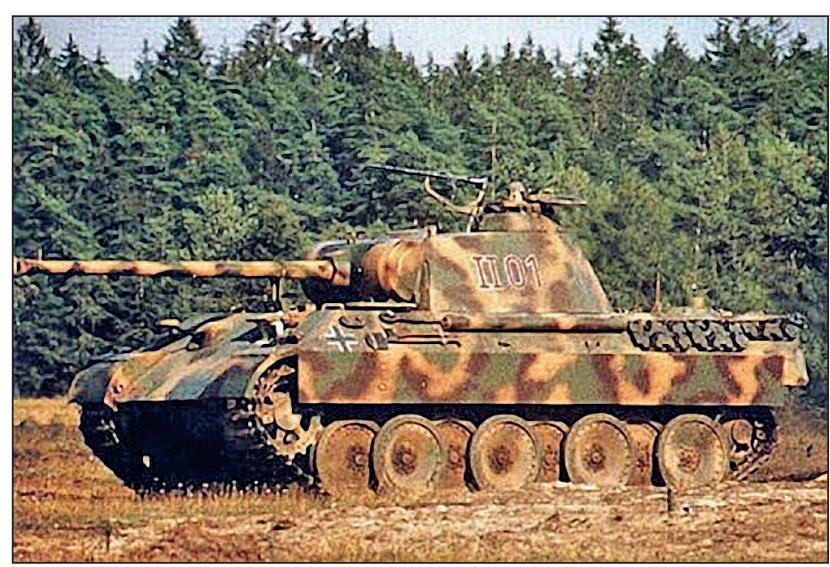

3. ábra. A Panther harckocsi egy korabeli fotón

Meggyőződésem, hogy ezek konzekvenciáit egy reális értéksorrend megállapításához egyenként és együttesen is figyelembe kell venni.

Vitathatatlan kiindulópont, hogy bármely haditechnikai eszközt - esetünkben a nehéz harckocsit - csak a minőségképességet meghatározó alapvető tulajdonságok együttes figyelembevétele mellett lehet reálisan értékelni. Hiába volt ugyanis egy nehéz harckocsi egyes vélemények szerint kiváló harcértékű eszköz, ha például:

- a konstrukció nem felelt meg a tömeggyárthatóság követelményének,

- megbízhatóságának alacsony foka miatt rendre meghibásodott,

- gyenge oldala volt a gyakori üzemanyag-feltöltés igénye,

- leginkább egy speciális feladatra volt alkalmas,

- kezelői nem voltak kellőképpen felkészülve,

- bonyolult volt és sok idő kellett rutinszerű kezelésének elsajátításához,

- a kérdéses típus csak a háború utolsó évében készült el, és harctevékenységekben alig vett részt,

- a harcoló egységek parancsnokai nem megfelelő módon vetették be azokat stb.

Rendkívül tanulságos megfigyelni azt is, hogy a második világháborút követően az adott harckocsi típus gyakorolt-e hatást más harckocsi-fejlesztésekre, vagy legalább részmegoldásai - az adott típusú futómű (pl. átlapolt futógörgők), a páncélzat-konstrukció (pl. öntvény páncél), vagy a motor-konstrukció (pl. négy- vagy kétütemú dízel) - megjelent-e más harckocsikon. Ha nem így történt, akkor az lényegében a megoldás „elhalásához” vezetett, ami maga is egyfajta közvetett, ugyanakkor vitathatatlan értékítéletnek tekinthető.

\section{SZAKIRODALOMI MEGÁLLAPÍTÁSOK A NEHÉZHARCKOCSI-TÍPUSOK SIKERESSÉGÉRŐL}

A második világháború első, második és harmadik legjobb harckocsijának rangsorolása a katonai szakirodalmat keleten és nyugaton egyaránt foglalkoztatta és foglalkoztatja még ma is. Az első öt helyre rendszerint a Tiger $E$, a Königstiger, az ISz-3-as, az ISz-2-es és újabban a Panther típusok kerülnek, többnyire ebben a sorrendben. Vajon helytálló ez a sorrend?

Lássunk ezzel kapcsolatban néhány véleményt az újabb keletű szakirodalomból!

„A korszerűtlen Otto-motor és függőleges páncélzat alkalmazásából fakadó többlet tömeg, a mozgékonyság hiá- nya, de leginkább a kis hatótávolság az, ami egyes nyugati elemzőket a Tiger harckocsik elmarasztalására indítja az ISz nehéz harckocsikkal szemben. Véleményük szerint „a történelem legsikeresebb harckocsijai...(közt) csak kevés igazán nagyszerű típusról lehet beszélni. A Panther és a Tiger megfelelnek az elvárásoknak, bár utóbbi korlátozott hatótávolsága ellene szól, de itt kell megemlíteni a szovjet Joszif Sztálin harckocsikat, különösen a 3. változatot, mely korának legerősebb harckocsija volt."1

Mások is vallják, hogy „az ISz-3 korának kétségkívül legfejlettebb nehéz harckocsija volt, nagyban befolyásolta a Nyugat saját harckocsi fejlesztéseit."2 Az újabb megközelítések szerint a másik elismert nehézharckocsi-típus a Pz. V. Panther. Magyar szerzők véleménye szerint „a Panther a második világháborús német harckocsik legsikerültebb típusa lett."3 Dr. S. Hart és Dr. R. Hart szakírók véleménye: „a Panther a II. világháború egyik legjobb harckocsija volt. Ennél a típusnál sikerült kialakítani a nagy erejü 75 mm-es löveg, a ferde síkú páncélzat és a mozgékonyság hatékony kombinációját." 4

Német szerzők írják: „szakmai körökben egyhangúan egyetértenek azzal, hogy a Panther volt a legsikeresebb német harckocsi-fejlesztés. Támadó és védelmi szerepkörben...egyaránt képes volt fölényben maradni az ellenfél harckocsijaival szemben, így minden német harckocsi közül a legjobb volt." ${ }^{\prime}$ A nyugati szakemberek tehát egyre gyakrabban második vonalba helyezik a Tiger programot, míg az ISz és Panther változatokat egyaránt a legjobbnak mondják

„A ISz-3-as a két rivális német harckocsival szemben fölényben volt tűzerejét - bár tűzgyorsaságát tekintve nem - és védettségét tekintve egyaránt.”“ Az ISz-3 „típust alacsony felépítése, páncélzatának sikeres formája és tűzereje tette korának legfejlettebb harckocsijává."7

Elegendőnek tartom ennyi idézet bemutatását ahhoz, hogy egyrészt néhány elterjedt hiedelmet a német Tigerek még ma is gyakran vallott egyértelmű fölényéről megkérdőjelezhessünk, másrészt lássuk a több vonatkozásban ugyan összecsengő, de közel sem megegyező véleményeket. A szakirodalomban tehát a sorrendiség megállapításának igencsak jellemzője a szubjektivitás, az egykori propaganda máig ható visszhangja és az igazolás nélküli állítások.

Ki kell emelnem, hogy alig találunk a haditechnikai eszközök harcértékének (minőségképességének) megállapítására kellően sokoldalú, úgynevezett több szempontú vizsgálatot, egzakt matematikai módszer alkalmazását pedig a legritkább esetben.

\section{Nehéz harckocsi volt-e a Panther?}

A részletesebb vizsgálatokat megelőzően választ kell még adnom a Panther besorolásának a kérdésére, mert egyes szakirodalmakban az közepes harckocsiként szerepel. A német hadrendi elemek megnevezése is bizonytalanságot kelt, esetenként közepesnek, más szervezeteknél nehéznek minősítik a típust.

Határozott véleményem, hogy egy harckocsi besorolását nem a megnevezése (könnyü, közepes vagy nehéz), hanem a műszaki tartalma és ebből is következően a harcászati, hadműveleti képességei alapján kell megítélni. A kérdés eldöntésére nagyon egyszerű módszert mutatok be. Ennek lényege: a közepes és a nehéz harckocsik tömeg- és méretadatai átlagértékeinek összevetése a vizsgált típuséval. Az 1. táblázat ebből a szempontból, és a jelenlegi elemzés igényeit tekintve, minden további magyarázatot feleslegessé tesz. 
1. táblázat. A Panther harckocsi besorolása - a harckocsi-kategóriák jellemző típusainak méret- és tömegadatok szerinti összevetése

\begin{tabular}{|c|c|c|c|}
\hline A) Közepes harckocsik & $\begin{array}{c}\text { Hosszúság } \\
\text { [mm] }\end{array}$ & $\begin{array}{c}\text { Szélesség } \\
\text { [mm] }\end{array}$ & $\begin{array}{l}\text { Tömeg } \\
\text { [tonna] }\end{array}$ \\
\hline Pz IV. & 7,0 & 2,88 & 25 \\
\hline T34/76 & 5,9 & 3,0 & 29 \\
\hline M4A1 & 6,16 & 2,67 & 31 \\
\hline 41M Turán & 5,5 & 2,44 & 19 \\
\hline \multirow{3}{*}{ B) Panther (Pz V.) ${ }^{\text {Átlag }}$} & 6,3 & 2,8 & 26 \\
\hline & 8,86 & 3,43 & 43 \\
\hline & 7,5 & 3,4 & 45 \\
\hline Pz VI.E & 8,24 & 3,7 & 57 \\
\hline ISZ-2 & 6,35 & 3,1 & 45 \\
\hline Churchill VII & 7,45 & 3,45 & 45 \\
\hline 44M TAS & & 3,5 & 38 \\
\hline C) Nehéz harckocsik & $\begin{array}{c}\text { [mm] } \\
\text { Hosszúság }\end{array}$ & $\begin{array}{c}\text { [mm] } \\
\text { Szélesség }\end{array}$ & $\begin{array}{l}\text { [tonna] } \\
\text { Tömeg }\end{array}$ \\
\hline
\end{tabular}

tömeg arány, a harckocsi úton, illetve terepen mért maximális sebessége, a talajnyomás értéke és a hatótávolság. A felsorolásból láthatóan ezek a műszaki jellemzők a három legfontosabb harci tulajdonság: a tűzerő, a mozgékonyság és a védettség nagybani leírására (minősítésére) is alkalmasak.

Egy, a nevesített adatokat tartalmazó táblázatból egyértelműen megállapítható az, hogy melyik jellemző szerint melyik harckocsi típus mutat kiemelkedő, melyik átlagos, melyik gyenge értéket. A legjobb és a legrosszabb értékek gyorsan megállapíthatók. Az adathalmaz tanulmányozása ugyanakkor még jó szakember számára sem teszi lehetővé, hogy a vizsgált típusok közötti egyértelmű megfelelőségi sorrendet, kellő biztonsággal felállíthassa. Egyes következtetések levonásához, a típusok nagyvonalú összevetéséhez, a szélső értékek megállapításához ugyanakkor egy ilyen táblázat értékes segítséget nyújt.

A Panther tehát egyértelműen a nehéz harckocsik kategóriájába helyezhető el, függetlenül attól, hogy a kategóriák definícióit a különböző szakirodalmak, lexikonok hogyan határozzák meg.

\section{A NEHÉZ HARCKOCSIK ÖSSZEVETÉSE A HARCÁSZATI-MÜSZAKI JELLEMZŐK ALAPJÁN}

A harckocsik értékelésére a harcászati-műszaki jellemzők egy meghatározott csoportját alkalmazzák. Ezek közé tartoznak többek között: az ekvivalens torony- és páncéltest vastagság, a löveg páncélátütő képessége 1000 méteren, a harckocsi tömege, a motor típusa és a motor maximális teljesítménye, a fajlagos teljesítmény, azaz a teljesítmény/
A 2. táblázatban szereplő adatok megbízhatósága ugyan gyakran képezi viták tárgyát, de a vitatott kérdések a gépkönyvek, gyári mérési adatok és kísérletek alapján kellö megbízhatósággal megválaszolhatók.

A döntéselméleti szakirodalom több módszert is tartalmaz az úgynevezett többparaméteres rendszerek - ilyenek a nehéz harckocsik is - egymáshoz viszonyított értékrendjének a megállapítására, éppen az említett táblázatok választott adataira támaszkodva. Egyik ilyen módszer a Kesselring-féle rangsorolás, amely egymáshoz viszonyítva egyértelműen besorolja a vizsgált harckocsi típusokat. Ezt mutatom be a 2. táblázatban, kiegészítve azt a következőkben tárgyalt konstrukciós fejlettségre irányuló vizsgálat eredményével. Utóbbival azt kívánom szemléltetni, hogy a két eltérő eljárás támogatja, erősíti egymást.

2. táblázat. Nehéz harckocsik értékelése Kesselring-módszerrel, és a műszaki fejlettség szerint

\begin{tabular}{|c|c|c|c|c|c|c|c|c|c|c|}
\hline $\begin{array}{c}\text { Típus/ } \\
\text { Tulajdonság }\end{array}$ & ISz-3 & ISz-2 & $\begin{array}{c}\text { M-26 } \\
\text { Pershing }\end{array}$ & Centurion & $\begin{array}{c}\text { Pz. VI } \\
\text { Tiger B }\end{array}$ & $\begin{array}{l}\text { WM } \\
\text { Tas }\end{array}$ & $\begin{array}{c}\text { Pz. V } \\
\text { Panther }\end{array}$ & $\begin{array}{c}\text { Pz. VI } \\
\text { Tiger E }\end{array}$ & $\begin{array}{c}\text { Churchil } \\
\text { VII }\end{array}$ & Ideál \\
\hline $\begin{array}{l}\text { Túzerő } \\
\text { (pc. átüt.) }\end{array}$ & $\begin{array}{l}7,81 \\
(185 \\
\mathrm{mm})\end{array}$ & $\begin{array}{l}6,25 \\
(160 \\
\mathrm{mm})\end{array}$ & $\begin{array}{c}8,75 \\
(200 \mathrm{~mm})\end{array}$ & $\begin{array}{c}3,6 \\
(118 \mathrm{~mm})\end{array}$ & $\begin{array}{c}8,75 \\
(200 \mathrm{~mm})\end{array}$ & $\begin{array}{l}4,06 \\
(125 \\
\mathrm{mm})\end{array}$ & $\begin{array}{c}5 \\
(140 \mathrm{~mm})\end{array}$ & $\begin{array}{c}5 \\
(140 \mathrm{~mm})\end{array}$ & $\begin{array}{c}0,625 \\
(70 \mathrm{~mm})\end{array}$ & 8,75 \\
\hline $\begin{array}{l}\text { Védettség } \\
\text { (ekvivalens } \\
\text { homlokpáncél } \\
\text { vastagság) }\end{array}$ & $\begin{array}{c}9 \\
(260 \\
\mathrm{mm})\end{array}$ & $\begin{array}{c}8 \\
(240 \\
\mathrm{mm})\end{array}$ & $\begin{array}{c}3 \\
(140 \mathrm{~mm})\end{array}$ & $\begin{array}{c}7 \\
(220 \mathrm{~mm})\end{array}$ & $\begin{array}{c}5,75 \\
(195 \mathrm{~mm})\end{array}$ & $\begin{array}{c}6.5 \\
(210 \\
\mathrm{mm})\end{array}$ & $\begin{array}{c}3 \\
(140 \mathrm{~mm})\end{array}$ & $\begin{array}{c}1 \\
(100 \mathrm{~mm})\end{array}$ & $\begin{array}{c}1 \\
(102 \mathrm{~mm})\end{array}$ & 9 \\
\hline $\begin{array}{l}\text { Harcászati } \\
\text { mozgékonyság } \\
\text { (harcjármű } \\
\text { sebesség) }\end{array}$ & $\begin{array}{c}5 \\
(40 \\
\mathrm{km} / \mathrm{h})\end{array}$ & $\begin{array}{c}5 \\
(40 \\
\mathrm{km} / \mathrm{h})\end{array}$ & $\begin{array}{c}5 \\
(40 \mathrm{~km} / \mathrm{h})\end{array}$ & $\begin{array}{c}5 \\
(40 \mathrm{~km} / \mathrm{h})\end{array}$ & $\begin{array}{c}4.33 \\
(38 \mathrm{~km} / \mathrm{h})\end{array}$ & $\begin{array}{c}5 \\
(40 \\
\mathrm{km} / \mathrm{h})\end{array}$ & $\begin{array}{c}6.66 \\
(45 \mathrm{~km} / \mathrm{h})\end{array}$ & $\begin{array}{c}4 \\
(37 \mathrm{~km} / \mathrm{h})\end{array}$ & $\begin{array}{c}0.66 \\
(27 \mathrm{~km} / \mathrm{h})\end{array}$ & 6,66 \\
\hline $\begin{array}{l}\text { Hadmúveleti } \\
\text { mozgékonyság } \\
\text { (hatótávolság) }\end{array}$ & $\begin{array}{l}5,5 \\
(200 \\
\mathrm{km})\end{array}$ & $\begin{array}{c}7,5 \\
(240 \\
\mathrm{km}) \\
\end{array}$ & $\begin{array}{c}4,3 \\
(176 \mathrm{~km})\end{array}$ & $\begin{array}{c}5 \\
(190 \mathrm{~km})\end{array}$ & $\begin{array}{c}1,5 \\
(120 \mathrm{~km})\end{array}$ & $\begin{array}{c}4 \\
(170 \\
\mathrm{km})\end{array}$ & $\begin{array}{c}3,5 \\
(160 \mathrm{~km})\end{array}$ & $\begin{array}{c}0.5 \\
(100 \mathrm{~km})\end{array}$ & $\begin{array}{c}2 \\
(130 \mathrm{~km})\end{array}$ & 7,5 \\
\hline Összesen & 27,31 & 26,75 & 21,05 & 20,6 & 20,33 & 19,5 & 18,16 & 10,5 & 4,285 & 32 \\
\hline Átlagolva: & 0,853 & 0,836 & 0,657 & 0,643 & 0,635 & 0,609 & 0.567 & 0,328 & 0,134 & 1 \\
\hline $\begin{array}{l}\text { Generáció } \\
\text { jellemzói }\end{array}$ & \multicolumn{2}{|c|}{$\begin{array}{l}\text { Öntvénypáncél } \\
\text { + dízelmotor }\end{array}$} & \multicolumn{2}{|c|}{$\begin{array}{c}\text { Öntvénypáncél } \\
\text { + befecskendezéses } \\
\text { Otto-motor }\end{array}$} & \multicolumn{3}{|c|}{$\begin{array}{l}\text { Döntött lemez páncél } \\
\text { karburátoros Otto-motor }\end{array}$} & \multicolumn{2}{|c|}{$\begin{array}{c}\text { Függőleges lemez } \\
\text { páncél } \\
+ \text { karburátoros } \\
\text { Otto-motor }\end{array}$} & \\
\hline
\end{tabular}




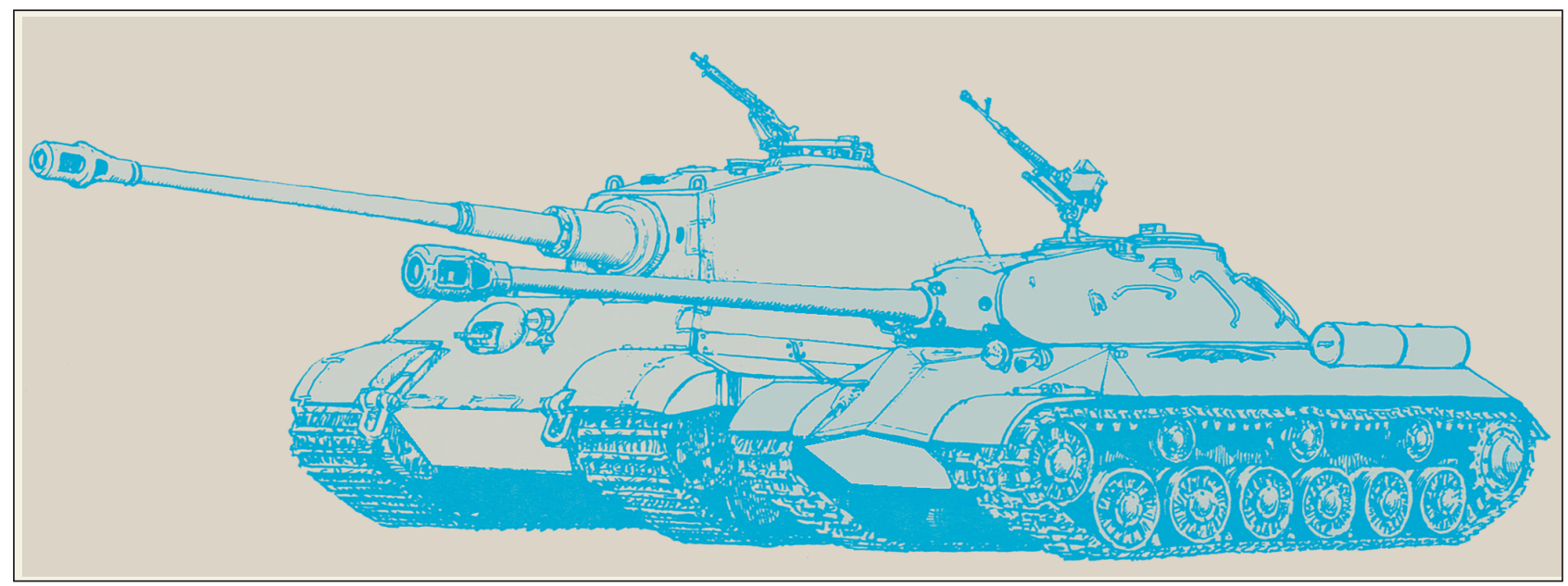

4. ábra. Királytigris és ISz-3-as nehéz harckocsi páncéltest-geometriájának összevetése

\section{KIEMELHETŐEN FONTOS RENDSZEREK MÜSZAKI FEJLETTSÉGE ALAPJÁN VÉGZETT ÉRTÉKELÉS}

A harckocsi típusok erőforrásuk jellege és a páncéltest, illetve a torony gyártási technológiája alapján generációs fejlettségi sorrendbe állíthatók. Külön-külön a két szempont tárgyalására a szakirodalom számos elemzéssel szolgál. Együttes vizsgálatukra ugyanakkor, a szerkesztésemmel készült „Nehéz harckocsik” című könyv megjelenését megelőzően, nincs információm. A vizsgálati mátrix felállításánál a motorokat a karburátoros Otto motor - befecskendezéses Otto motor - dízelmotor; a páncélzatokat a szegecselt síklemez páncélzat - hegesztett, függőleges síklemez páncélzat - hegesztett, döntött-hajlított páncélzat - öntött páncélzat fajtákra osztottam fel. Ez a felosztás mindkét esetben a fejlettségi sorrendet is jelenteti. Így összesen 12 mátrix elem jön létre, amelyekbe a harckocsi típusok mindegyikét el lehet helyezni.

Egy típus elhelyezkedése a táblázatban tehát akkor mutat kedvezőbb, korszerübb műszaki megoldást, ha a motor és a páncélzat tekintetében a vetélytárséhoz viszonyítva egyik szempontból sem alacsonyabb, és legalább egy szempontból magasabb fejlettséget mutat. A táblázat segítségével új szempontrendszer alapján tudjuk összevetni és rangsorolni a harckocsi típusokat. Ez az értékelés önmagá- ban kevés ugyan, de más értékelésekkel együtt alkalmazva feltétlenül gazdagítja a vizsgált típusok megítélését, segíti az összehasonlítás pontosságát, illetve növeli a megállapítások megbízhatóságát. Ezért egészítettem ki az előbbi, Kesselring-féle táblázatot ennek a vizsgálatnak a megfelelő eredményeivel. (3. táblázat)

\section{A NEHÉZHARCKOCSI-TÍPUSOK ÉS A HADÁSZATI KULTÚRÁK KAPCSOLATA}

Az értékelés új, eddig még nem alkalmazott szegmensének tartom az alkalmazott harckocsi típusoknak az egyes hadászati kultúrák igénystruktúrája szerinti vizsgálatát. Itt nem valamiféle sorrendiség kialakítása a cél, hanem annak megállapítása, hogy az adott nehéz harckocsi megfelelt-e az alkalmazó haderő által képviselt hadászati kultúra sajátos, annak lényegéből logikusan következtethető igényeinek, vagy nem. A különböző hadászati kultúrák haditechnikai eszközökkel szembeni igénye a védettség, a mozgékonyság és a tűzerő tekintetében más és más volt. Általánosságban a mozgáscentrikus hadászati kultúra (német haderő) sorrendben a mozgékonyságot, a tűzerőt és a minőséget helyezte előtérbe. Ez a harckocsik műszaki paramétereit (harci lehetőségét) tekintve a mozgékonyság, a

3. táblázat. Nehéz harckocsik minősítése múszaki fejlettség alapján

\begin{tabular}{|c|c|c|c|c|}
\hline ERŐFORRÁS & $\begin{array}{c}\text { Első generáció } \\
\text { Szegecselt síklemez } \\
\text { páncélzat }\end{array}$ & $\begin{array}{l}\text { Második generációs } \\
\text { Hegesztett } \\
\text { függőleges síklemez } \\
\text { páncélzat }\end{array}$ & $\begin{array}{l}\text { Harmadik generációs } \\
\text { Hegesztett döntött- } \\
\text { hajlított síklemez } \\
\text { páncélzat }\end{array}$ & $\begin{array}{c}\text { Negyedik generációs } \\
\text { Öntvény páncélzat } \\
\text { (torony) }\end{array}$ \\
\hline $\begin{array}{l}\text { Első generációs } \\
\text { Karburátoros } \\
\text { Otto-motor } \\
\left(\eta_{\mathrm{e}}=24 \% \text {-ig) }\right.\end{array}$ & T-35 (1935-1939) & $\begin{array}{c}\text { Tiger I (1942-1944) } \\
\text { Churchill III-VII } \\
(1942-1945)\end{array}$ & $\begin{array}{l}\text { Panther (1942-1945) } \\
\text { Tiger II (1944-1945) }\end{array}$ & \\
\hline $\begin{array}{l}\text { Második generációs } \\
\text { Befecskendezéses } \\
\text { Otto-motor } \\
\left(\eta_{\mathrm{e}}=26 \% \text {-ig }\right)\end{array}$ & & & & $\begin{array}{l}\text { M-26 Pershing (1945) } \\
\text { Centurion (1945) }\end{array}$ \\
\hline $\begin{array}{l}\text { Harmadik generációs } \\
\text { Diesel-motor } \\
\left(\eta_{\mathrm{e}}=36 \%-\mathrm{ig}\right)\end{array}$ & & $\begin{array}{l}\text { KV-1 (1939-1940) } \\
\text { KV-2 (1939-1940) }\end{array}$ & & $\begin{array}{c}\text { KV-1 (1941-1942) } \\
\text { KV-85 (1943) } \\
\text { ISz-2 (1944-1945) } \\
\text { ISz-3 (1945) }\end{array}$ \\
\hline
\end{tabular}




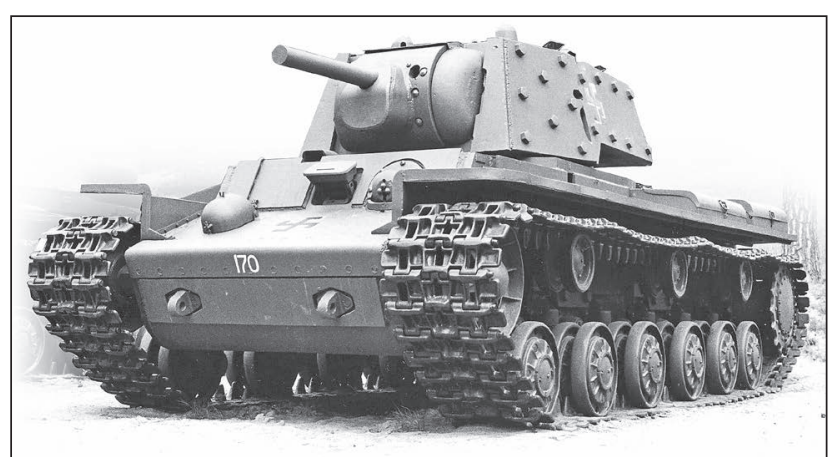

5. ábra. Szovjet KV-1-es nehézharckocsi, dízelmotorral

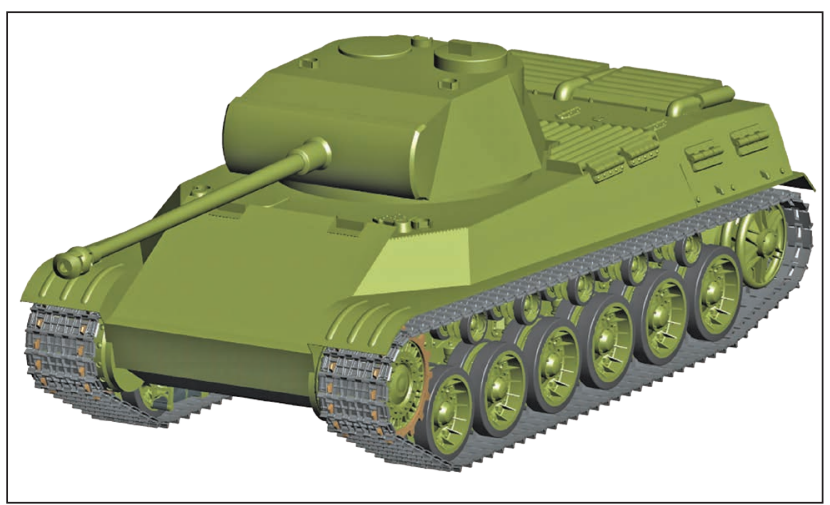

6. ábra. A magyar Tas nehézharckocsi grafikus ábrázolása.

A harckocsi nem készült el, a prototípus bombázás áldozata lett

tűzerő és a védettség prioritást követelte meg. ${ }^{8}$ Általában egy erői-eszközei megóvását előtérbe helyező, kockázatkerülő anyagcentrikus hadászati kultúra (brit és amerikai haderő) a tüzerő után a védettséget preferálta és a mennyiséget ezt követően tartotta lényeges szempontnak, ami a harckocsik megkövetelt műszaki paramétereire is természetesen igaz volt. A tömeges hadászati kultúra (szovjet-

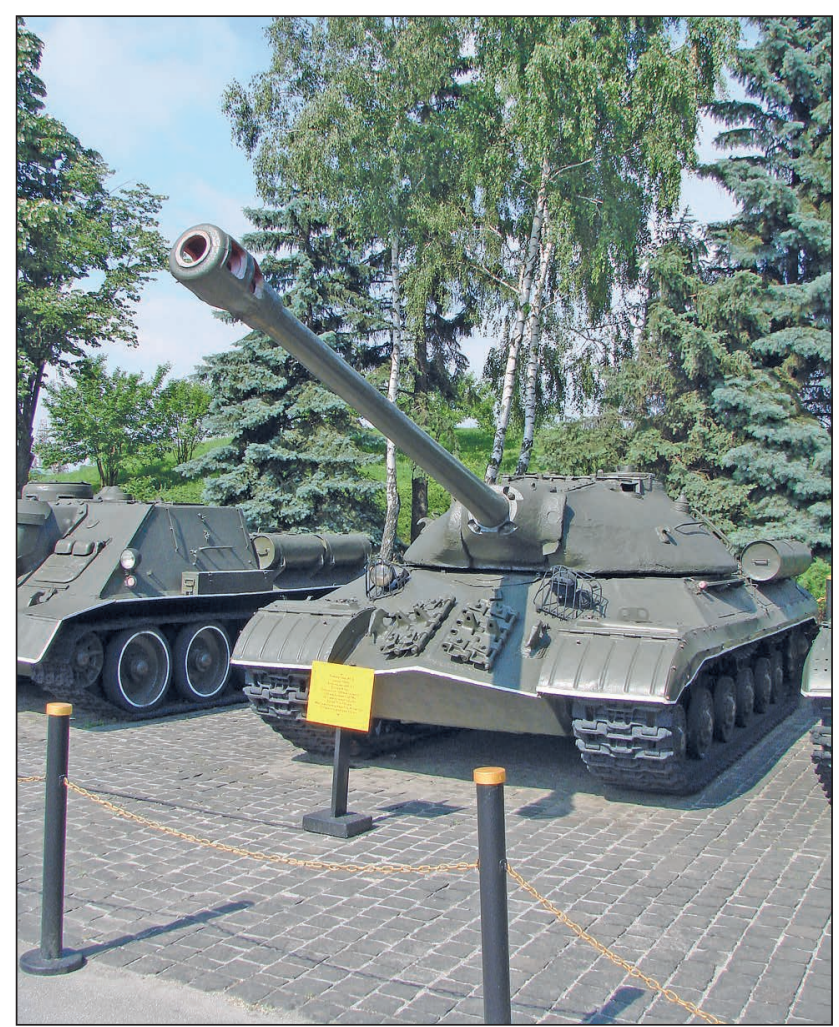

8. ábra. Szovjet ISz-3-as nehéz harckocsi a kijevi múzeumban. A típust hegesztett páncéltest, kedvező kialakítású öntvénytorony, illetve dízelmotoros meghajtás jellemezte

orosz haderő) esetén a jellegzetes fontossági sorrend: a tűzerő, a mennyiség és a mozgékonyság volt. ${ }^{9}$ Harckocsik esetében ez a nagy mennyiségű, közepes minőségű, tömegesen gyártható eszköz előállításán és rendszeresítésén alapult. Az egyes hadászati kultúrák által megkívánt, és a nehézharckocsi-típusok által megvalósított harcászati paramétersorrend viszonyát a táblázat mutatja be.

7. ábra. ISz-3-as nehéz harckocsi egy izraeli múzeumban. A 122 mm-es löveg meggyőző tưzerőt képviselt

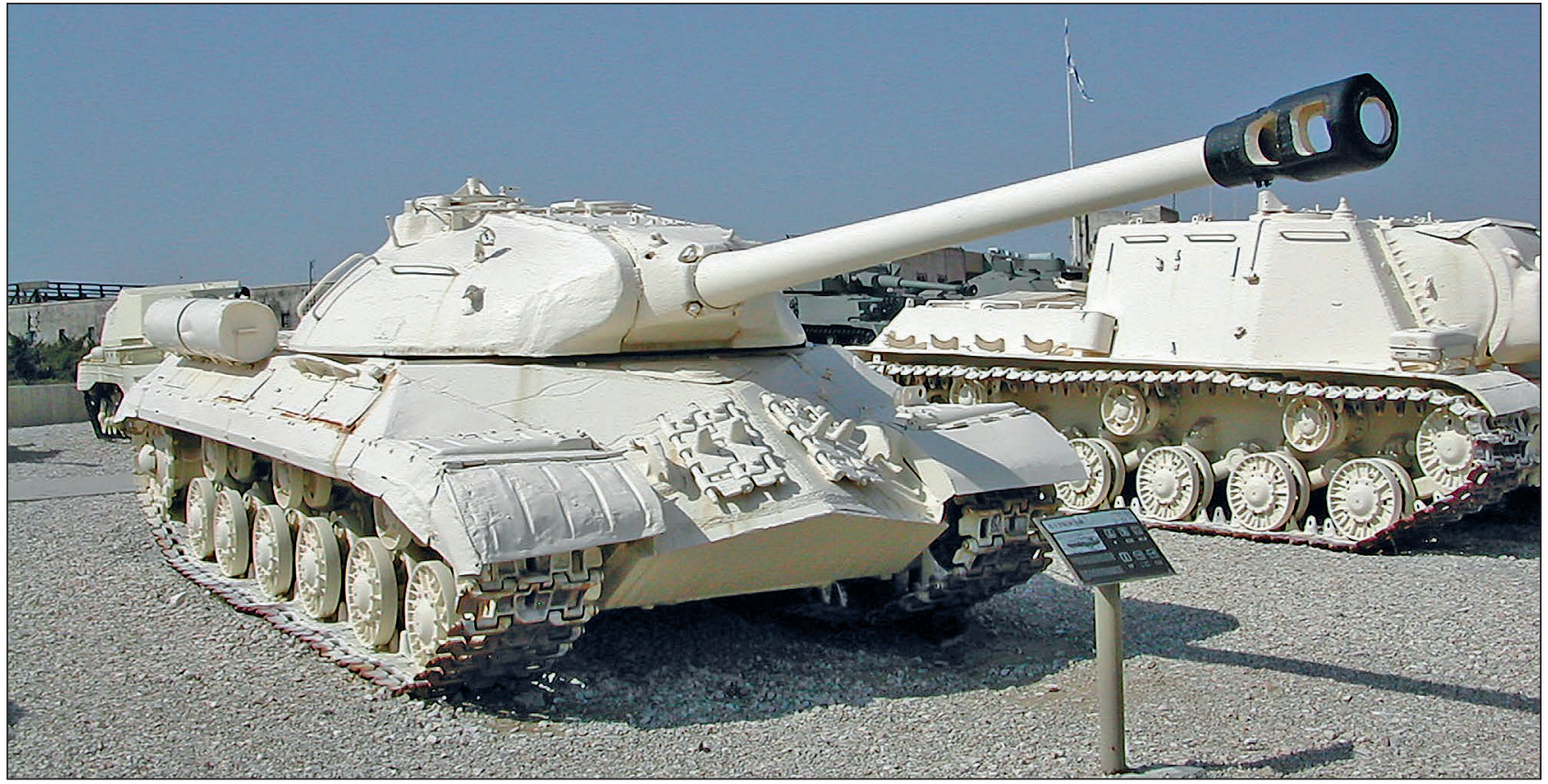


4. táblázat

\begin{tabular}{|c|c|c|c|c|}
\hline Hadászati kultúra & $\begin{array}{l}\text { A hadászati kultúrának } \\
\text { megfelelő prioritás } \\
\text { (fontossági sorrend) }\end{array}$ & $\begin{array}{l}\text { Nehéz } \\
\text { harckocsi } \\
\text { típus }\end{array}$ & $\begin{array}{l}\text { Nehéz harckocsi } \\
\text { típusnál meg- } \\
\text { valósított prioritás }\end{array}$ & $\begin{array}{l}\text { Az összhang } \\
\text { vizsgálata }\end{array}$ \\
\hline \multirow{3}{*}{$\begin{array}{l}\text { Tömeges } \\
\text { hadászati kultúra } \\
\text { (Szovjetunió) }\end{array}$} & \multirow{3}{*}{$\begin{array}{l}\text { 1. T (tüzerő) } \\
\text { 2. M (mozgékonyság) } \\
\text { 3. V (védettség) }\end{array}$} & $\mathrm{KV}-1$ & $\mathbf{M} \rightarrow \mathbf{V} \rightarrow \mathbf{T}$ & Nincs összhang \\
\hline & & $\mathrm{KV}-2$ & $\mathbf{T} \rightarrow \mathbf{V} \rightarrow \mathbf{M}$ & Nincs összhang \\
\hline & & ISz-2 és ISz-3 & $\mathbf{T} \rightarrow \mathbf{M} \rightarrow \mathbf{V}$ & Összhang \\
\hline \multirow{3}{*}{$\begin{array}{l}\text { Mozgáscentrikus } \\
\text { hadászati kultúra } \\
\text { (Németország) }\end{array}$} & \multirow{3}{*}{$\begin{array}{l}\text { 1. M (mozgékonyság) } \\
\text { 2. T (tűzerő) } \\
\text { 3. V (védettség) }\end{array}$} & Pz. VI Tiger E: & $\mathbf{V} \rightarrow \mathbf{T} \rightarrow \mathbf{M}$ & Nincs összhang \\
\hline & & Pz. V Panther & $\mathbf{M} \rightarrow \mathbf{T} \rightarrow \mathbf{V}$ & Összhang \\
\hline & & Pz. VI Tiger B & $\mathbf{V} \rightarrow \mathbf{T} \rightarrow \mathbf{M}$ & Nincs összhang \\
\hline \multirow{3}{*}{$\begin{array}{l}\text { Anyagcentrikus } \\
\text { hadászati kultúra } \\
\text { (Egyesült Államok, } \\
\text { Nagy-Britannia) }\end{array}$} & \multirow{3}{*}{$\begin{array}{l}\text { 1. } \mathbf{T} \text { (tüzerő) } \\
\text { 2. V (védettség) } \\
\text { 3. } \mathbf{M} \text { (mozgékonyság) }\end{array}$} & Churchill VII & $\mathbf{V} \rightarrow \mathbf{T} \rightarrow \mathbf{M}$ & Nincs összhang \\
\hline & & $M-26$ & $\mathbf{T} \rightarrow \mathbf{M} \rightarrow \mathbf{V}$ & Megfelelő összhang \\
\hline & & Centurion & $\mathbf{T} \rightarrow \mathbf{M} \rightarrow \mathbf{V}$ & Megfelelő összhang \\
\hline
\end{tabular}

Rövidítések: $\mathbf{T}$ - tűzerő; $\mathbf{M}$ - mozgékonyság; $\mathbf{V}$ - védettség,

Értelmezés: például az $\mathbf{M} \rightarrow \mathbf{V}$ azt jelenti, hogy a vizsgált szempontból a mozgékonyság fontosabb, mint a védettség

\section{HADÁSZATI KULTÚRÁKNAK MEGFELELŐ, ÉS A VIZSGÁLt TíPUSOK ÁLTAL MEGVALÓSÍTOTT HARCÁSZATI PARAMÉTER PRIORITÁSOK ÖSSZHANGJA}

A tömeges hadászati kultúrát képviselő Szovjetunió nehézharckocsi-típusai esetében látható (4. táblázat), hogy a KV-1-esnél messze a tűzerő előtt helyezkedett el a nagyfokú harcászati és hadműveleti mozgékonyság, míg a védettség észszerű középértéket valósított meg. A KV-1-es fő fegyverzete azonos volt a közepes harckocsikéval, ami azt eredményezte, hogy nem tudott hatékonyan szembeszállni a Tiger E-vel. Elméletileg a KV-2 típusnál kiküszöbölték a fő fegyverzet tűzerejénél megállapított hiányosságokat, ekkor azonban egyaránt problémák keletkeztek a működőképesség (toronyforgatás) és a mozgékonyság területén. Valóban hatékony szovjet nehéz harckocsinak csak a tűzerő-mozgékonyság-védettség prioritást a működőképesség fenntartása mellett megvalósító ISz-2/3 típusok tekinthetők.

A német Tiger és Königstiger esetében az elvileg elsősorban megkövetelt hadműveleti és harcászati mozgékonyságot messze háttérbe szorították, így azok nem feleltek meg a magas manőverigényű, mozgáscentrikus hadászati kultúra igényeinek. A német haderő harctevékenysége még a háború utolsó éveiben is jelentős mértékben

9. ábra Brit Centurion harckocsi a nehéz harckocsi kategória alsó határán

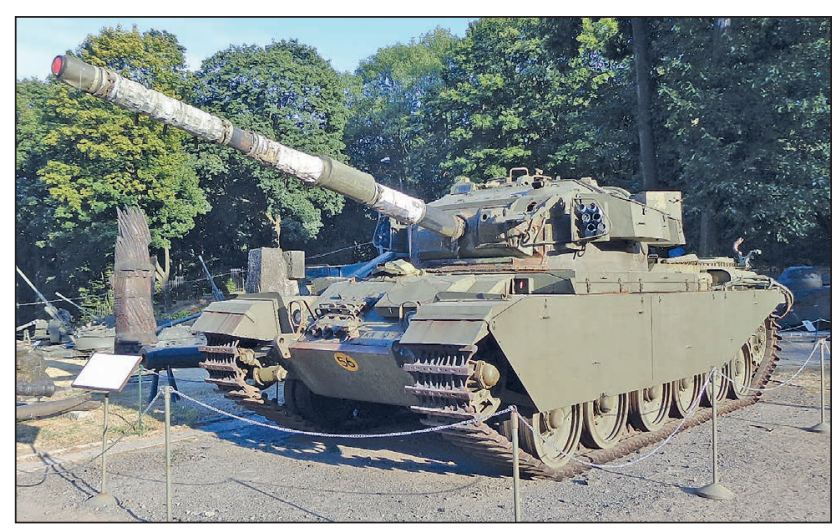

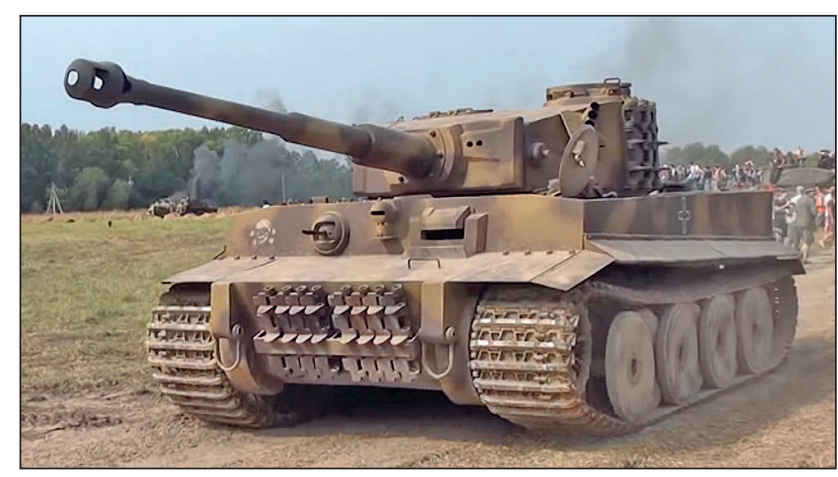

10. ábra. Német Tiger nehéz harckocsi. Függőleges beépítésű páncéllemezek és Otto-motoros meghajtás jellemezte a konstrukciót

manőverező harctevékenységen alapult. „A hadászati védelembe kényszerített német csapatok a területvédelmet az ellenlökésekkel és ellencsapásokkal váltogatták... A német hadászati védelemre jellemző aktív védekezés során az azonnali ellenlökéseket, illetve megtervezett ellentámadásokat indító német páncéloscsapatok... abban az esetben harcolhattak a leghatásosabban, ha gyors ellenlökéseket indítottak, és a már megindult szovjet offenzívába sikerült oldalról, a szárnyakra mért csapással beletámadniuk. Az ekkor kialakuló páncélos-találkozóharcban jobban érvényesülhetett a német páncélos-technika tűzfölénye és a németek rugalmasabb harcvezetési felfogása." ${ }^{10} \mathrm{~A}$ német haderő szempontjából éppen fentiek okán a Panther (és a tervezett Panther II.) sokkal inkább megfelelt (volna) a katonai igényeknek, mint a Tiger $\mathrm{E}$ és a Tiger $\mathrm{B}$.

A brit nehézharckocsi-építés területén elsőként megjelenő Churchill-nek még a VII változata is csak olyan tǔzerővel rendelkezett, mint egy közepes harckocsi, ami e típust a klasszikus harckocsik elleni szerepkörben korlátozottan tette alkalmassá feladatai ellátására. (A típus - a Black Prince példája alapján - a nagyobb tűzerejü irányba csak teljes átépítés árán volt továbbfejleszthető.) A Churchill speciális változatai viszont különleges feladatok - müszaki, illetve támogató - ellátására kiválóan alkalmasnak bizonyultak.

A felsorolt típusok harcászati tulajdonságait kifejező paraméterek sorrendje egy részük esetében megfelelt az al- 


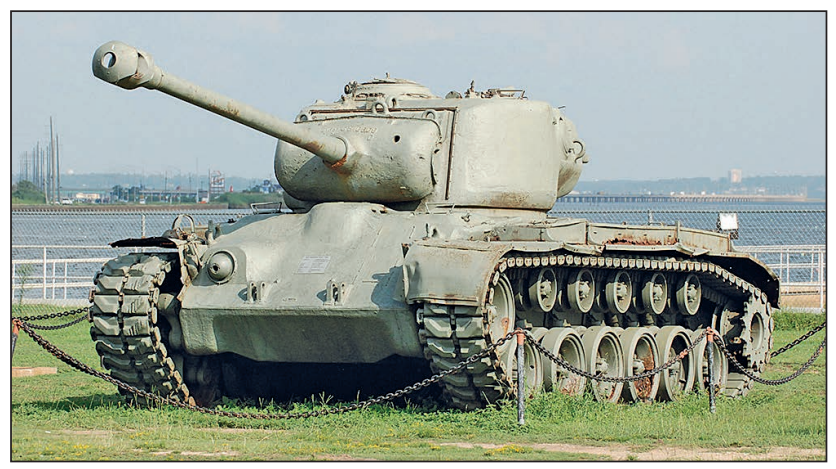

11. ábra. Amerikai M-26-os nehéz harckocsi. Öntvény páncélzat és V-8-as benzinmotor jellemezte a típust

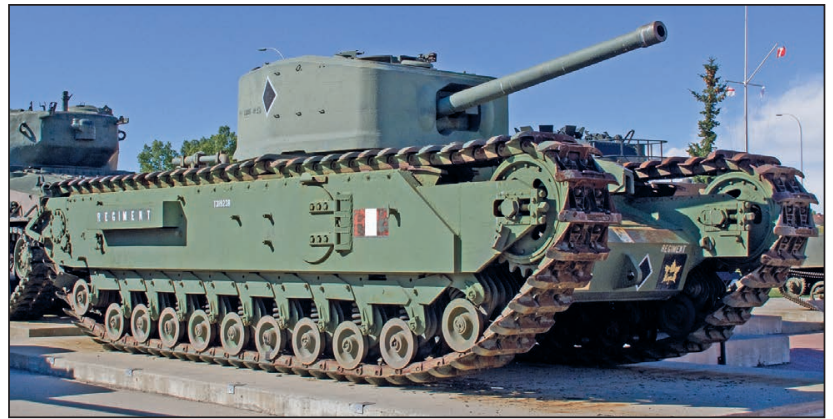

12. ábra. Brit Churchill nehéz harckocsi, meglehetősen elavult kialakítással

kalmazó nemzet hadászati kultúrája által megköveteltnek, más részüknél ez az összhang nem áltt fenn. Az adott hadászati kultúrában alkalmazott haditechnikai eszközök akkor értek el a háború során igazán jelentős sikereket, ha konstrukciós jellemzőik minden vonatkozásban megfelelő összhangot mutattak a nemzeti hadászati kultúrájuk sajátos követelményrendszerével.

A nehézharckocsi-típusok harcászati-műszaki jellemzőik alapján történt összevetése és az adott nemzet hadászati kultúrájának való megfelelés kérdésében elvégzett értékelések együttes figyelembevétele alapján az egyértelműen kedvezőnek (kiválónak) tekinthető típusok a következők voltak: az ISz-2-es szovjet, az M-26-os amerikai és a Pz. $\mathrm{V}$-ös német nehéz harckocsik. ( $\mathrm{Az}$ Isz-3-ast, mivel rendszeresítése későn történt, és bevetésére az európai hadszíntéren nem került sor, az összesített értékelésnél ebben az esetben nem vettem figyelembe).

13. ábra. Szovjet T-35-ös nehéz harckocsi, szegecselt páncélzattal, több toronnyal és benzinmotorral. Már a harmincas évek végén is elavultnak számított

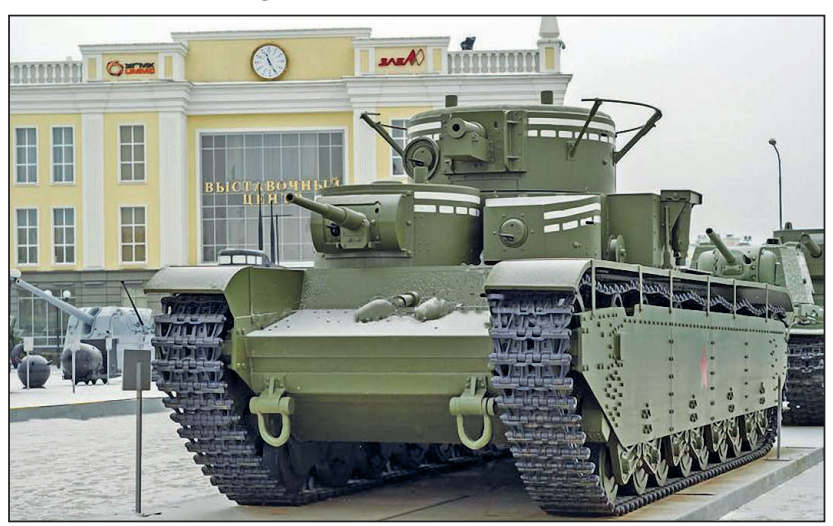

A nehézharckocsi-fejlesztések eredményességének megítélésében jelentős szerepet játszik a második világháborús típusok hatása a későbbi generációkra. Ebből a szempontból kiemelhető az ISz-3-as, a (rendkívül hosszú ideig rendszerben tartott) Centurion, és az M-26-os, míg több megoldásában sem talált követöre a Königstiger és a Churchill.

A hazai harckocsi-tervezés kiválósága szempontjából feltétlenül meg kell említenünk, hogy a megtervezett, és részben megépített Tas harckocsi elvi értékelése nagyon hasonló eredményt hozott volna, mint a kor legalkalmasabbnak tekintett típusai. A magyar konstruktőrök asztaláról teljesen új típus került ki, amely a számított harcászatitechnikai paraméterei alapján akár a $\mathrm{Pz}$. V Pantherrel is felvehette volna a versenyt.

\section{MELYEK VOLTAK TEHÁt A LEGJOBB (AZ „IDEÁLIS”) NEHÉZ HARCKOCSIK?}

Az elvégzett vizsgálatok eredményeit figyelembevéve, már nem szubjektív megállapítás, hanem több szempontból is alátámasztott megállapítás az alábbi:

A Panther és az ISz-2-es nehéz harckocsikkal előállítóik és alkalmazóik eredményesen bizonyították, hogy azokat az önálló alkalmazást segítő támogató elemekkel megerősítve, dandár struktúrában nemcsak áttörő feladatokra, hanem általános rendeltetésű alap harckocsiként is alkalmazni lehet. Kiemelten fontos, hogy a németek jövőbe mutató módon célul tűzték ki a teljes mértékben Panther típussal feltöltött hadosztályok felállítását is. Összességében mind a német, mint a szovjet tapasztalatok a széles körben alkalmazható nehéz harckocsi koncepcióját igazolták vissza, amelynek leginkább ez a két típus felelt meg. A világháborúban még nem bontakozott ki teljességgel a nehéz harckocsi későbbi uralkodó szerepe, de ennek jelei már kitapinthatóak voltak.

A mai alap harckocsi kialakulásának gyökerei tehát elsősorban a második világháborúban több szempontból egyaránt sikeres német és szovjet nehéz harckocsikhoz nyúlnak vissza.

A címben feltett kérdésre tehát, ma már nem egyedülálló, de az eddigieknél sokkal megalapozottabb válasz: a Panther és az ISz-2-es.

\section{JegYzetEK}

1 Ford, Roger: A világ híres harckocsijai 1916-tól napjainkig. Hajja, Debrecen, 2004. 173-174. o

2 Forty,George: Tankok világenciklopédiája. Athenaeum, Budapest, 2005. 79. o.

3 Bonhardt - Sárhidai - Winkler: A Magyar Királyi Honvédség fegyverzete. Zrínyi, Budapest, 1989. 136. o.

4 S. Hart - R. Hart: A II. világháború német páncélosai. Hajja és fiai könyvkiadó, Debrecen, 1999. 95. o.

5 Senger, F. M. - Etterlin: German Tanks of World War II. (München, 1965) Arms and Armour Press, London 1973. 67. o.

6 Ford, Roger: A világ híres harckocsijai 1916-tól napjainkig. Hajja, Debrecen, 2004. 66. o.

7 George Forty: Tanks of World War Two. Osprey Publication Co., London, 1995. 173. o.

8 Kovács - Turcsányi - Berek - Csabai - Héjja: A hadművészet és a haditechnika kapcsolata, egymásra gyakorolt hatása. (Kerekasztalbeszélgetés) Új Honvédségi Szemle 1994. 1. sz. 36 o.

9 Turcsányi Károly: A haderő harckocsi igénykielégítési folyamatának makroszemléletű vizsgálata. MTA doktori értekezés, Budapest, 2008. 58. o

10 Szabó Péter - Számvéber Norbert: A keleti hadszíntér és Magyarország 1943-1945. 2. köt. Puedlo kiadó, Budapest, 2001. 235-236. o. 